\title{
A CONTESTED PAST. MEMORY WARS DURING THE TWELVE YEARS TRUCE (1609-21)*
}

\author{
Jasper van der Steen
}

In 1609, Spain and the Dutch Republic signed a Twelve Years Truce after waging war for more than forty years. In the running up to and during the ceasefire, the highest military commander Prince Maurice as well as orthodox Calvinists actively opposed efforts to forge a lasting peace. This anti-peace lobby tried to convince government authorities, and the people of the Netherlands in general, that the Spanish had a track record of not keeping their word and that they could, therefore, not be trusted.

To substantiate their claim of Spanish unreliability, anti-peace propagandists reduced the history of the Revolt against the Habsburg overlord Philip II of Spain to a selection of gruesome episodes in order to remind people of the cruelties Spanish rulers and their soldiers were capable of. ${ }^{1}$ The result was a historical canon: a relatively inclusive and non-confessional story aimed at convincing as many people as possible that the war should be resumed. But the inclusive character of this narrative was put to the test when new internal divisions compromised the unity of the Republic. Around 1610, a religious quarrel broke out about the Reformed doctrine of double predestination between two professors of theology in Leiden: Jacobus Arminius and Franciscus Gomarus. The disagreement between the two men was ostensibly a matter for academics only, but in fact it almost dragged the state into civil war. ${ }^{2}$

* Research for this article was funded by an NWO VICI grant for the research project Tales of the Revolt. Memory, oblivion and identity in the Low Countries, 1566-17oo.

1 Judith Pollmann, Het oorlogsverleden van de Gouden Eeuw (Leiden: Universiteit Leiden, 2008), 9-10; Jasper van der Steen, 'Goed en fout in de Nederlandse Opstand', Holland 43 (2011), 82-97, there 87-88.

2 Jan den Tex, Oldenbarnevelt: Bestand, $1609-1621,5$ vols. (Haarlem: H.D. Tjeenk Willink, 1966), vol. 3; A.Th. van Deursen, Bavianen en slijkgeuzen. Kerk en kerkvolk ten tijde van Maurits en Oldebarnevelt (Franeker: Van Wijnen, 1998); for more concise explanations of the troubles, see: A.Th. van Deursen, Mensen van klein vermogen. Het kopergeld van de Gouden Eeuw (Amsterdam: Ooievaar, 1996), 304-311; W. Nijenhuis, 'De publieke kerk veelkleurig en verdeeld, bevoorrecht en onvrij' in P. Blok (ed.), Algemene geschiedenis der Nederlanden 6 (1977-1989); T. Kootte (ed.), Rekkelijk of precies. Remonstranten en contraremonstranten ten 
The disagreement between these theologians was about predestination and human free will. ${ }^{3}$ Arminius believed that the doctrine of predestination allowed for the human initiative to reject God's offer of salvation. Otherwise there was a risk that some people might mistakenly believe that God could be held accountable for human sin. For Gomarus, however, ideas of human involvement in the Lord's gift were anathema because they impinged on His absolute sovereignty. ${ }^{4}$ This seems a very technical doctrinal discussion, yet A.Th. van Deursen has shown that in the struggles between the supporters of these two men, not only doctrinal but also political arguments were used. ${ }^{5}$ Developing this point further, Carolina Lenarduzzi found that propagandists from both opposition groups were the first to appropriate public memories of the Revolt on a large scale to conduct their political disagreements. ${ }^{6}$

The political and religious conflicts in the Dutch Republic during the Twelve Years Truce (1609-21) thus involved a contest for the moral ownership of the communal past. Public memories of the Revolt in the 1560 s, $70 \mathrm{os}$ and $80 \mathrm{~s}$ that had been used to unite Netherlanders against the foreign enemy now became important weapons to eliminate opponents on the domestic political scene. I will build on Lenarduzzi's work and assess how this shift from external to internal usage occurred. To do so, this chapter examines the 'memory war' between Arminian 'Remonstrants' and Gomarist 'Counter-Remonstrants' in the 1610 s and offers an explanation of why canonical memories were time and again used as a rhetorical battleground on which opposing political factions carried out their disputes. The term 'memory war' used in this section of the volume refers to conflicts that are not themselves conflicts about the past but in which nonetheless the past is invoked to bolster arguments in the present. What this chapter will show is that when historical interpretations are used to support two contradictory agendas, a political disagreement can become also a conflict about the appropriation and correct reading of the past. An analysis of this phenomenon contributes to our understanding of why

tijde van Maurits en Oldenbarnevelt (Utrecht: Rijksmuseum Het Catharijneconvent, 1994); Judith Pollmann, Religious choice in the Dutch Republic. The reformation of Arnoldus Buchelius (1565-1641) (Manchester: Manchester University Press, 1999).

3 Van Deursen, Bavianen en slijkgeuzen, 228-229.

4 Nijenhuis, 'De publieke kerk', 334.

5 Van Deursen, Bavianen en slijkgeuzen, 275-309.

6 Carolina Lenarduzzi, “'De oude geusen teghen de nieuwe geusen”. De dynamiek van het oorlogsverleden ten tijde van het Twaalfjarig Bestand', Holland 43 (2011), 65-81, there 65-69. 
public memories of the Revolt remained politically relevant in the seventeenth-century Low Countries.

The rhetorical use of history in the Remonstrant and Counter-Remonstrant struggles of the 1610 s will be discussed in three sections. The first will involve the debate over which group had the oldest claim of being Reformed. The second case will deal with history as a rhetorical trap. It will examine the appropriation of Prince William of Orange's heritage by both parties. Prince William was the father of Maurice and served as the leader of the Revolt until his death in 1584. The final case will examine the use of references to the Spanish army commander Fernando Álvarez de Toledo, duke of Alba (1507-82) as the Revolt's darkest villain. Before exploring these cases, I will introduce the religious troubles briefly.

\section{Religious Troubles in the 1610 s and the Authority of History}

Around 1610, Arminian clergymen in the Reformed public church were increasingly threatened with suspension by their colleagues because of their dissenting views, notably about the doctrine of predestination. ${ }^{7}$ As a minority they began to seek support from government authorities. In January 1610, forty-four prominent Arminian clergymen presented a Remonstrance to the States of Holland, arguing for a more flexible and inclusive public church. ${ }^{8}$ Hence they became known also as Remonstrants. Holland's Advocate Johan van Oldenbarnevelt (the highest official of the province) chose to support the Remonstrants for purposes of social harmony. ${ }^{9} \mathrm{He}$ accepted their minority views in the public church as he preferred groups in society to get along rather than make a fuss about doctrinal differences. Followers of Gomarus (or Counter-Remonstrants), however, were orthodox Calvinists who rejected both the idea of a doctrinally flexible church and of government interference in the church.

Oldenbarnevelt's first major move was to force through the Resolution for the Peace of the Churches (1613), which was drafted by Hugo Grotius,

\footnotetext{
7 Judith Pollmann, Een andere weg naar God. De reformatie van Arnold Buchelius (15651641) (Amsterdam: Bert Bakker, 2000), 128-129.

8 Jonathan I. Israel, The Dutch Republic. Its rise, greatness, and fall, 1477-1806 (Oxford: Clarendon Press, 1995), 425.

${ }^{9}$ For Oldenbarnevelt's religious convictions, see: Den Tex, Oldenbarnevelt III, 1-35; for toleration as a means to preserve civic harmony: Van Deursen, Bavianen en slijkgeuzen, 251; A. Algra en H. Algra, Dispereert niet. Twintig eeuwen historie van de Nederlanden 2 (Franeker: T. Wever, 1978), 55; Joke Spaans, Haarlem na de Reformatie. Stedelijke cultuur en kerkelijk leven (The Hague: Smits, 1989).
} 
Pensionary of Rotterdam and a sympathiser of the Arminians. ${ }^{10}$ The Resolution, adopted by the States of Holland in 1614, ordered both factions to bury the hatchet and agree on a policy of peaceful co-existence within the public church. ${ }^{11}$ Holland thus mandated toleration and instructed that the issue of predestination not be discussed in church services. ${ }^{12}$ Here, the States effectively decided unilaterally that the Arminian stance on predestination was acceptable within the public church. CounterRemonstrants saw this action as an undesirable compromise on their faith and as an intolerable intervention of the state in church affairs. ${ }^{13}$

In the course of the 1610 s, a string of political associations came to be attached to the religious disagreements. Counter-Remonstrants, for instance, argued that the teachings of their Arminian opponents smacked of Papist sympathies or even of 'Pelagianism'. ${ }^{14}$ If a believer could himself influence God's offer of election by doing good deeds, what then distinguished the Remonstrants from evil Catholics? ${ }^{15}$ Furthermore, Gomarists increasingly regarded the Remonstrants as unpatriotic because they sought support from the Advocate Johan van Oldenbarnevelt. Oldenbarnevelt's patriotic credentials had been tarnished by his successful efforts for the ceasefire with Spain. At the height of the conflict from 1617 onwards, Counter-Remonstrant propagandists even raised suspicions that Oldenbarnevelt was in fact a crypto-Catholic himself and in league with the Catholic powers France and Spain.

10 States of Holland, Resolvtie vande doorluchtige moghende heeren Staten van Hollandt ende West-Vrieslandt (The Hague, 1614), Kn. 2109.

11 Resolutie Vande Doorluchtige Moghende Heeren Staten van Hollandt ende WestVriesland tot den Vrede der Kercken (The Hague, 1614).

12 Kootte (ed.), Rekkelijk of precies, 18.

13 See for instance: Jacobus Trigland, Antwoorde op dry vraghen, dienende tot advijs in de huydendaechse swaricheden (Amsterdam, 1615), Kn. 2191; Vincent van Drielenburch, Cort examen ende sententie Johannis Vtenbogaerts over seker tractaet, welckes tytel is: Verdediging van de resolutie [...] der Staten van Hollandt [...]. totten vrede der kercken (Amsterdam, 1615), Kn. 2195 .

14 See, for instance, anonymous, Een kort en waerachtich verhael, wat voor een grouwelijck ghevoelen dat de Arminianen, Vorstianen, ofte nieuwe Arrianen, Pelagianen, Socinianen, Samosatianen ghesocht hebben in de Ghereformeerde Kercke in te voeren, en in kort hier teghen gestelt het ghevoelen der Ghereformeerde Kercke (s.l., 1612), Kn. 2009; Jacobus Trigland, Kerckelycke geschiedenissen begrypende de swaere en bekommerlijcke geschillen, in de Vereenigde Nederlanden voor-gevallen, met serselver beslissinge, ende aenmerckingen op

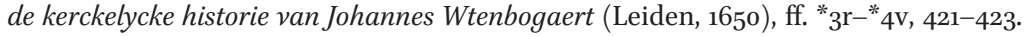

15 Arminians, in turn, also accused Counter-Remonstrants of Papist tendencies. The author of the following pamphlet calls the Gomarist clergymen who opposed government interference in church order 'Jonge Pausen vanden Ouden Paus van Rome' or 'young popes of the old pope of Rome'; Robbert Robbertsz Le Canu, Ratelwachts roeprecht, tegent boeck

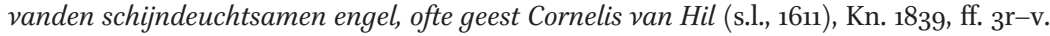


In January 1617, Prince Maurice unambiguously chose side in the conflict and began supporting the Counter-Remonstrants. Oldenbarnevelt and Prince Maurice both lived in Arminian-dominated The Hague. Tensions rose when the Counter-Remonstrants, who refused to attend the Arminian services, wanted a church building to be allocated to them. In the summer they had still attended Gomarist services in neighbouring Rijswijk, but the winter rendered such Auslauf less attractive, especially for the young and elderly. ${ }^{16}$ Things changed when Oldenbarnevelt asked the stadholder's assistance in keeping the Counter-Remonstrants from causing unrest in the city. ${ }^{17}$ Maurice was invited to appear at a meeting of the Delegated Councillors, together with the High Council, the Court of Holland, the Audit Chamber and the magistrates of The Hague on 13 January $1617 .^{18}$ The English ambassador Sir Dudley Carleton wrote a biased report of this assembly. According to his account, the regents asked Maurice to prevent the Counter-Remonstrants from causing disturbances and, if necessary, to use his own princely guard or forces from outside the city to keep them in check. Maurice declined, arguing that his guard was there only to protect his own person and that military forces were for the defence of the country against foreign threats. In reaction to the continued pressure of the magistrates, Maurice 'called for the register-book, wherein his oath was set down, which he took in the year 86; at which time he entered into the charge he now holds for the service of the state'. ${ }^{19}$

The prince ordered the register-book for a purpose, it 'being read in all their presences, and therein this article noted in particular, that both he and the states do mutually bind themselves, even to the last drop of blood, for the defence of the Reformed religion, which was the first ground of their quarrel, and for which his father lost his life' ${ }^{20}$ Carleton never made any attempts to disguise his sympathy for the Counter-Remonstrant camp,

16 Den Tex, Oldenbarnevelt, vol. 3, 439; for the term 'Auslauf', see Benjamin Kaplan, Divided by faith. Religious conflict and the practice of toleration in early modern Europe (Cambridge Mass.: Belknap Press, 2007), 145.

17 A.Th. van Deursen, Maurits van Nassau. De winnaar die faalde (Amsterdam: Bert Bakker, 2005), 256.

18 Den Tex, Oldenbarnevelt, vol. 3, 441; the term 'Delegated Councillors' is a translation of 'Gecommitteerde Raden'. This institution was the executive committee of the States of Holland: Robert Fruin, Geschiedenis der staatsinstellingen in Nederland tot den val der Republiek (The Hague: Martinus Nijhoff, 1980), 224-226.

19 Dudley Carleton to Ralph Winwood, 14 January 1617, in Letters to and from Sir Dudley Carleton, Knt. during his embassy in Holland from January 1615/1616 to December 1620 (London, 1775), 87.

20 Ibid., 87. 
but if he can nonetheless be trusted in his account, Maurice invoked the memory of his deceased father William of Orange to point out that the Revolt had been foremost a struggle for the Reformed religion. ${ }^{21}$ 'Sitting in the same chair which was anciently the place of the counts of Holland, [...] [where] he hath not been called before this time since 86', the Prince ordered the magistrates to assign a building to the Counter-Remonstrants and allow them free worship. ${ }^{22}$ The problem with this description is that Maurice's oath did indeed include a pledge for protection of the 'true Reformed religion', but strictly speaking it did not specify this to be the Counter-Remonstrant variant of the faith. ${ }^{23}$ Unfortunately, there is no way of knowing whether the Prince indeed acted according to Carleton's description. It is obvious, however, that the ambassador thought it a good thing to have the Orange dynasty's support for the Counter-Remonstrant cause.

Reliable or not, Carleton was an astute observer of Dutch politics and his accounts tend to be accurate reflections of Counter-Remonstrant sentiments. He wrote to the English secretary of state that the original cause of this disorder is easily discovered to be Arminianism: the effects will be faction in the state, and schism within the church'. ${ }^{24} \mathrm{He}$ continues his report ominously, writing that 'the factions begin to divide themselves betwixt his excellency and monsieur Barnevelt, as heads, who join to this present difference their antient quarrels' ${ }^{25}$ These ancient quarrels were about the negotiation of the truce with Spain and the Habsburg Netherlands. More recently, Maurice had also fallen out with Oldenbarnevelt over the Advocate's wish to support the pro-Spanish and Catholic French government in its domestic struggles against Huguenot rebels, support which Maurice disapproved of. ${ }^{26}$ To underline the urgency of his concerns, Carleton recounts the washing ashore of three whales-'a popular vanity of prognosticating change', which nevertheless he 'cannot ommit'. ${ }^{27}$ Two of them beached on the Island of Brill 'in the very places and instant

21 See also J. Bax, Prins Maurits in de volksmeening der 16e en 17e eeuw (Amsterdam: H.J. Paris, 1940), 25; Den Tex, Oldenbarnevelt III, 443-444.

22 Carleton to Winwood, 14 January 1617, in Letters to and from Sir Dudley Carleton, 87.

23 Hugo Grotius, Verantwoordingh van de vvettelijcke regieringh van Hollandt ende WestVrieslant (Paris, 1622), 121; see also: C.P. Hofstedde de Groot, Honderd jaar uit de geschiedenis der Hervorming in de Nederlanden (1518-1619) (Leiden: A.W. Sijthoff, 1883), 403.

24 Carleton to Winwood, 14 January 1617, in Letters to and from Sir Dudley Carleton, 88.

25 Ibid., 89 .

26 Den Tex, Oldenbarnevelt, vol. 3, 444.

27 Carleton to Winwood, 14 January 1617, in Letters to and from Sir Dudley Carleton, 89. 
time of these tumults'. Brill had been the place where the rebels against Spain first took control in $\mathbf{1 5 7 2}$. Carleton is even more surprised because 'it is remembered, that at the first breaking out of these country wars, there were two of the like bigness driven on shore in the river of Schelde below Antwerp, and at the framing of the Truce one here in Holland' ${ }^{28}$

On 23 July 1617, Maurice and his princely entourage openly attended Counter-Remonstrant services in the Kloosterkerk in The Hague, defying his own Arminian preacher Uytenbogaert. ${ }^{29}$ Johan van Oldenbarnevelt saw the stadholder's behaviour as the provocation it was likely intended to be. Eager to restore his damaged authority, he showed his muscle and encouraged the States of Holland to adopt the Scherpe Resolutie or sharp resolution. This measure allowed cities to employ their own waardgelders, mercenary soldiers, to enforce toleration of religious nonconformists within the public church. ${ }^{30}$

The British ambassador was one of the most vehement opponents of this measure. On 6 October 1617 , he felt compelled to speak out against government support for the Remonstrants and addressed the States General who were assembled in The Hague. The text was subsequently printed and distributed. ${ }^{31}$ Carleton explains that 'to seeke the originall of this euill any further backe then the time of Arminius Professor at Leyden, were to disguise the fact'. He wanted to make clear that not the doctrinal documents of the Reformed church were the source of all troubles but that Arminius was the culprit. ${ }^{32}$ He provides a succinct history of the rise of the troubles and deplores the 'animosities and alterations betweene the magistrates, sowernesse and hatred amongst the people'. Then, he portrays nostalgically the situation before the troubles. Before the rise of Arminius and his schismatic behaviour, there had been 'union in the church and estate; good correspondence between the magistrates; Christian love

\footnotetext{
28 Ibid., 89.

29 Den Tex, Oldenbarnevelt, vol. 3, 490; Poelhekke, Frederik Hendrik, 65-66; Van Deursen, Maurits, 258.

${ }^{30}$ Van Deursen, Bavianen en slijkgeuzen, 271-272.

31 Carleton to Thomas Lake, 22 November 1617, in Letters to and from Sir Dudley Carleton, 206-207; Taurinus, Weegh-schael, om in alle billickheydt recht te over-vveghen de oratie vanden [...] heere Dvdley Carleton [...] inde vergaderinghe der [...] Staten Generael (s.l., 1617), 4.

32 Dudley Carleton, The speech of Sir Dudley Carlton lord ambassadour for the king of Great Britaine, made in the assembly of the lords the Estates Generall of the vnited provinces of the Low Countries. Being assembled at the Haghe. Touching the discord and trovbles of the church and policie, caused by the schismatic doctrine of Arminivs (London, 1618), 2.
} 
and charitie among the people'. ${ }^{33}$ To solve the problems, Carleton urged the States General to hold a national synod: 'I say nationall, because the euill being passed from province to province, a provincial synode is not sufficient'. ${ }^{34}$

A national synod had been a tricky subject from the start of the religious troubles. First of all, delegating church affairs to a national synod was placing the matter out of the hands of the provincial government, and that was exactly what the Arminians did not want. As a minority, they needed government protection to counterbalance the orthodox Calvinist majority within the Reformed church. Furthermore, a national synod was seen by the majority of cities in Holland as a challenge to provincial sovereignty. ${ }^{35}$ Carleton waves these objections aside. He begins by making a rhetorical appeal as a foreigner: 'I will not play the busie-body in aliena Republica, therein to iudge how much euery prouince in particular ought in such occasions to yield to the publike'. And then he proceeds to do just that: "let them not forget the oath by which they are consolidated and closed up into one body which is the vnion of Vtrecht grounded upon religion'. ${ }^{36}$

The Union of Utrecht (1579) was, de facto, the constitution of the Republic. And although it guaranteed the sovereignty of each province, especially in matters of religion, 'this ought to bee vnderstood'-according to Sir Dudley-'soundly for the maintenance of the pure \& sincere religion'. The articles which prescribed provincial autonomy in matters of religion, notably article 13, were originally intended to allow Holland to uphold Reformed purity 'without being exposed to the will and pleasure of the other provinces which at that time were not reduced to such a union of the Church as they enjoy at this present'. ${ }^{37}$ Here, Carleton refers to the time around 1580 when, in many provinces in the east and south of the rebel United Provinces, the Reformed church was less developed and under constant pressure from Habsburg troops who were trying to reconquer the territory, quash the insurrection and 'recatholicise' the population. Now, the situation was different since the Reformed church had

33 Ibid., 5 .

34 Ibid., 6.

35 Resolutiën der Staten-Generaal. nieuwe reeks, 1610-1670: derde deel, 1617-1618, ed. J.G. Smit (The Hague: Martinus Nijhoff, 1975), 286.

36 Carleton, The speech, 7.

37 Ibid., 7; see for article 13 of the Union of Utrecht: Simon Groenveld, Unie-BestandVrede. Drie fundamentele wetten van de Republiek der Verenigde Nederlanden (Hilversum: Verloren, 2009), 65. 
become the established public church in all of the provinces. The original intentions of the Union of Utrecht's articles about provincial autonomy regarding religious matters had been overtaken by the new reality of Calvinist hegemony.

It was in this historical setting that propagandists from the Remonstrant and Counter-Remonstrant camps tried to convince the population of the validity of their viewpoints. Increasingly, secular political arguments complemented doctrinal arguments, and memories of the Revolt became political weapons.

\section{Who Was First?}

Counter-Remonstrants accused their Arminian opponents of introducing novelties into the public church. The severest allegation was that Arminians sought to dilute the most important doctrinal documents of the Reformed church in the Netherlands so that Arminian ideas about predestination could become accepted practice. Ever since the Synod of Emden in 1571, these documents were officially the Heidelberg Catechism and the Belgic Confession, and it was the duty of consistories and classes to uphold them. ${ }^{38}$ Counter-Remonstrants argued that both standard documents had been fought for in the war against Catholic Spain. They felt that changing the catechism and confession would be tantamount to casting off the achievements of the Revolt. ${ }^{39}$

Arminians found a way around the Counter-Remonstrant criticism that they sought to introduce novelties by emphasizing that although, as a religious group, they had come into existence only in the early seventeenth century, they acted more in the spirit of the Reformation than did their adversaries. ${ }^{40}$ Arminians claimed, for instance, that the authority of the Bible was far more important than the Reformed church order. Their Gomarist adversaries' claim of antiquity was clearly nothing compared to the antiquity and status of the Bible. Prince Maurice's Remonstrant court

38 Trigland, Kerckelycke geschiedenissen, ff. * $3{ }^{\mathrm{r}}-{ }^{*} 4 \mathrm{v}, 18-19$.

39 [Johan Casimir Junius], Wederlegginge van de Weegschaal onlangs uytgegeven tegens d'oratie des ed. heere Dvdley Carletons (s.l., 1618), 154.

40 See for instance the discussion about the supposed nieuwlichterij of the Arminians in Uytenbogaert, Copye and its retort in [ Jacobus Trigland], Klaer |ende grondich teghenvertoogh, van eenighe kercken-dienaren van Hollandt ende West-Vrieslandt, gestelt tegen seker vertoogh der remonstranten (Amsterdam, 1617); see also: Van Deursen, Bavianen en slijkgeuzen, 230. 
chaplain Johannes Uytenbogaert (who had been one of the first authors of the 1610 Remonstrance) used this argument. In one of his pamphlets he sneers: "The history of 40 years on which the Counter-Remonstrants pride themselves is real novelty compared to the history of Holy Scripture and the first Christendom'. ${ }^{41}$

Interestingly, though, the rhetoric of seniority proved irresistible even for the learned Arminian clergyman Uytenbogaert. To strengthen his argument, he tells the reader that 'there are in these lands many preachers now dead and some still alive, old men: who have declared and still declare never to have had different sentiment than the current Remonstrants do now' ${ }^{42}$ He pointed to the example of Rotterdam preacher Jan Ysbrantsz, who from the very beginning of the Reformation in that city 'hearing of Calvin's predestination already at that time publically refuted it, and that some old members noticing that some others sought to introduce it, departed for that reason from the church'.43 And in the city of Hoorn, Clement Maertensz, one of the oldest retired clergymen in Holland, 'frequently declared that from the beginning of his service onwards he had and had learned no other feeling regarding the predestination than that of Melanchton, and to have learned such from Hardenberg, one of the very first preachers of our reformation in Emden' ${ }^{44}$ Hence the Counter-Remonstrant claim of being more truly Reformed was, Uytenbogaert felt, inconsistent with the evidence from the past. But perhaps more importantly, he felt it was necessary to draw from the recent past to make this statement.

\section{What would William of Orange Do?}

By accusing them of jeopardizing the religious achievements of the Revolt, Counter-Remonstrants had pushed Arminians into a defensive mode. In search of an effective offensive strategy, Arminian clergyman and propagandist Jacob Taurinus from Utrecht expanded the rhetorical repertoire of the Remonstrants by appropriating the Revolt's secular heritage. In one of his pamphlets, Taurinus addresses the allegorical 'Maiden of Holland' and

41 Johannes Uytenbogaert, Copye van seker vertooch onlanghs bij eenighe predicanten der ghereformeerde kercke ghedaen [...]. roerende de oudtheyt vande gereformeerde leere (Delft, 1617), f. a3r.

42 Ibid., f. a4v.

43 Ibid., ff. a4v-bir.

44 Ibid., f. bir. 
seeks to sway her to the Remonstrant cause. First of all, he reminds her of the province's illustrious history of independence. 'Eight hundred years and more it is past that you have never been overlorded (although fiercely fought against)'. Is Holland now to abandon this proud tradition? 'That I think not: thou has suffered too much and fought too bloodily for more than forty years'. ${ }^{45}$ The implication is that Remonstrants should be considered the true inheritors of the Revolt's legacy.

In 1617, Taurinus wrote another influential pamphlet in which he adopted the national hero William of Orange as the retrospective protector of the Remonstrant cause. ${ }^{46}$ According to Taurinus, a reconstruction of Prince William's motivation for entering the war could be used to prove that he did not act primarily from religious motives. The author could thus show that the Counter-Remonstrant pursuit of Calvinist orthodoxy contradicted the original intention of the Revolt. To prove his point, he cites well-respected histories and in doing so does not shy away from recalling painful episodes such as the iconoclastic furies of 1566. During these furies, Catholic church property was destroyed by Protestant fanatics. For Taurinus, the episode confirmed that religious extremism leads to unrest. He notes that, at the time, William of Orange 'could not condone the breaking of the images [...] for which reason he also did not remain without discredit or slander among part of the zealots' ${ }^{47}$ By 'zealots', Taurinus refers to militant Calvinists like Jan van Hembyze and Peter Dathenus from Ghent who had criticised Prince William's confessional elasticity in the 1570 s and 80 . The Prince, then, had denounced religious extremists, even though it had made him unpopular among some of his supporters.

45 [Jacobus Taurinus], Ernstighe aenspraeck, aen de maeght van Hollandt (s.l., 1917), 3.

46 [Jacobus Taurinus], Na-Sporingh / hoe ende in vvat manieren, De door-luchtighe, ende hoogh-ghebooren vorst, de prince van Orangien, hooghloffelijcker memorie, de beschermenisse deser landen heeft aenghenomen, om de Nederlantsche Belijdenisse / als in allen deelen met Godts woordt accorderende / te mainteneren: en t'gevoelen der Contra-Remonstranten, int stuck vande predestinatie met den aencleven vandien, als Schrifmatich over al in te voeren (1617); according to Carolina Lenarduzzi this is the first time that the legacy of William of Orange is invoked for political purposes in the religious polemic during the Twelve Years Truce: Lenarduzzi, ' "De oude geusen teghen de nieuwe geusen"', 73; yet, earlier instances are known; on the Remonstrant side: Johannes Uytenbogaert, Verdedigingh vande resolvtie der [...] Staten van Hollant ende West-Vrieslant, totten vrede der kercken, teghen seker libel, gheintituleert Antwoort op drie vraghen (Amsterdam, 1615), f. ***3v; and on the CounterRemonstrant side: Van Drielenburch, Cort examen, f. bir.

47 [Taurinus], Na-Sporingh, 9 . 
The pamphlet by Taurinus was not received well at all among CounterRemonstrants. The English ambassador in The Hague, especially, was not pleased. He called it a book of 'vulgar language in conformity to the discourse of mons. Barnevelt'. Like other Gomarists, he lambasted Taurinus' assertion that the Revolt was 'for civil respects only', and he claimed that this Arminian wanted 'to wound count Maurice through his father's sides'. In response, the ambassador insisted that William of Orange fought the war against Spain for three reasons: the inquisition, the building of citadels and the injustice, all three of which, he wrote, 'are now again practiced by the Arminian faction'. ${ }^{48}$ Here we see that the ambassador gave his adversaries a taste of their own medicine. He came up with his own interpretation of the past in reaction to the Arminian propaganda.

The anonymous author of a particularly popular Counter-Remonstrant pamphlet The Right Track was also disgusted by Taurinus' interpretation of history, stating: 'When I saw the title, I thought that a grateful Netherlander sought to circulate the highly praiseworthy deeds and name of the [...] Prince'. That first impression proved false, however, for after having read the booklet, the anonymous author 'found that it was made in disparagement of his Princely Excellency's well-deserved and immortal honour'. ${ }^{49}$ What stands out in the anonymous author's text is the elaborate scholarly apparatus. Just like Taurinus, he cites William of Orange's famous Apology (1581) multiple times. In 1580 Prince William had been declared an outlaw by Philip II of Spain due to his treasonous conduct. To exonerate himself of the charges raised against him, the Prince had written an apologia. ${ }^{50}$ But the anonymous author disagrees with Taurinus' interpretation of the text and sets himself apart by his annotation.

In the disputed section, William of Orange writes: 'I mind not here (my Lords) to enter into this question, which is the true Religion'. ${ }^{51}$ Yet, where Taurinus had left it at that, the anonymous author reveals that the Prince's subsequent words clarify that he merely thought religion was the domain of clergymen and therefore fell outside his own area of expertise. The view that religion was, according to Prince William, best left to the church must

48 Carleton to Winwood, 30 October 1617, in Letters to and from Sir Dudley Carleton, 196.

49 Anonymous, De rechte spore ende aenwijsinghe, dat de [...] prince van Orangien [...] de bescherminghe der Nederlanden heeft aenghenomen voor de waerachtige religie, tegen de tyrannije der Spangiaerden (s.l., 1617), 3.

50 William of Orange, Apologie, ofte verantwoordinghe des doerluchtighen ende hooghgeborenen vorsts ende heeren, heeren Wilhelms [...] teghen den ban [...] ghepubliceert by den coningh van Spaegnien (Leiden, 1581).

51 Ibid., 5 . 
have been appealing to Counter-Remonstrants, who disapproved of government interference in the church. For the reader who wanted to check for himself what William had actually written, the anonymous author refers to: 'page 98 [of the Apology] that one can find in the last Edition printed in Leiden Anno 1609 or in the one printed in 1581 with Charles Silvius with the biggest Type [on] page 165 or with the other Type [on] page $111{ }^{5}{ }^{52}$ By citing multiple editions, the author lends weight to his argument and undermines that of his adversary. He enables his readers to look up his references and verify the authenticity of the citations, while pointing to the sloppy and biased Arminian interpretation of the source.

Apart from his view that Taurinus misinterpreted the source, the author points out that in other writings the Prince's concern for the maintenance of the Reformed religion becomes abundantly clear.

If he were to research the many old writings, commissions, and instructions by the Prince of Orange in the years $1567,1568,1569,1570,1571,1572$, and subsequent years, until he was killed so cruelly and murderously [...] he would find this to have been his chief aim, above all to further the honour and service of God, to protect the oppressed Christians, and maintain the privileges and liberties of these lands. ${ }^{53}$

Again like Taurinus, to bolster his agenda he draws on the well-known historians Pieter Bor and Emanuel van Meteren who wrote standard works about the Revolt. ${ }^{54}$ Taurinus refers to these historians to demonstrate, for example, that William of Orange respected the authority of the provincial state assemblies, even when they were dominated by Catholics. ${ }^{55}$ To him, this was evidence that Orange could not have been driven primarily by religion and that it was religious freedom the Prince was after. The author of The Right Track read Bor and Van Meteren differently and concludes that William of Orange struggled 'against the duke of Alba and his Spanish and Hispanised followers', who in turn waged war against the heretics. Thus, William fought not for religious freedom but rather to defend the true Reformed religion. ${ }^{56}$ Such an interpretation placed the old prince in an entirely different light, namely as a protector of the faith and more specifically as the guardian of the Counter-Remonstrant profession.

\footnotetext{
52 Ibid.

53 Ibid., 13.

54 Pieter Christiaensz Bor, Oorspronck, begin ende aenvang der Nederlantscher oorlogen, beroerten ende borgerlijcke oneenicheyden (Utrecht, 1595); Emanuel van Meteren, Belgische ofte Nederlantsche historie, van onsen tijden (Delft, 1599).

55 Taurinus, Na-Sporingh, 7.

56 Ibid., 12-13.
} 


\section{The Trap of History}

We have seen how a group who took the initiative of referring to the past to argue a case practically compelled its opponent to do the same. Another good example of this phenomenon is the way comparisons with the duke of Alba served to vilify one's opponent. In the Counter-Remonstrant print entitled Image of the Old and New Time we see the Advocate Johan van Oldenbarnevelt presiding over a table in the presence of several of his advisors, one of whom is whispering evil advice into his ear (figure $1 b$ ). In the text beneath the picture, two viewers discuss what they see. One of them exclaims: 'Hang on! Who do I see there? [...] Hey mate, look at it, how well it is cut: Hey let us have a look: is it not Barnevelt? The illustrious president, full of power and great force?'. ${ }^{77}$ The other, however, replies: 'Tis a president alright, but he is named the duke of Alba'. ${ }^{58}$

And indeed, by flipping the top half of the picture the duke of Alba suddenly replaces Oldenbarnevelt (figure 1a). Alba was one of the darkest characters in the canonical narrative about the Revolt in the Dutch Republic. At the beginning of the conflict in the 1560 s and 1570 , he and his Council of Troubles condemned thousands of Netherlanders to death. The background reveals the Grand Place of Brussels in 1568 where the prominent counts of Egmont and Horne are about to be executed as political dissidents. The two persons in the text squabble for a bit about their discrepant interpretations, and then a third person enters the room. He understands the confusion and explains that there is, after all, not much difference between Oldenbarnevelt and the duke of Alba.

At the height of the conflict between the Remonstrants and CounterRemonstrants, Maurice marshalled all the support he could get, charged Johan van Oldenbarnevelt with treason and ordered the Advocate's arrest. The statesman, who was then seventy-one years old, was beheaded on 13 May 1619. A few months before, the much disputed National Synod had assembled at Dordrecht. It condemned Arminian theology and ordered the expulsion and exile of all Arminian clergymen who persisted in their doctrinal deviance. In the face of more persecutions, Remonstrant authors, too, began to draw analogies with the duke of Alba. It was, for example, Alba who in 1568 had captured one of Oldenbarnevelt's predecessors:

57 Anonymous, Afbeeldinghe van den ouden ende nieuwen tijdt / Met een t'samenspraeck van Beste-maet en Botte-maet (s.l., 1618).

58 Ibid. 


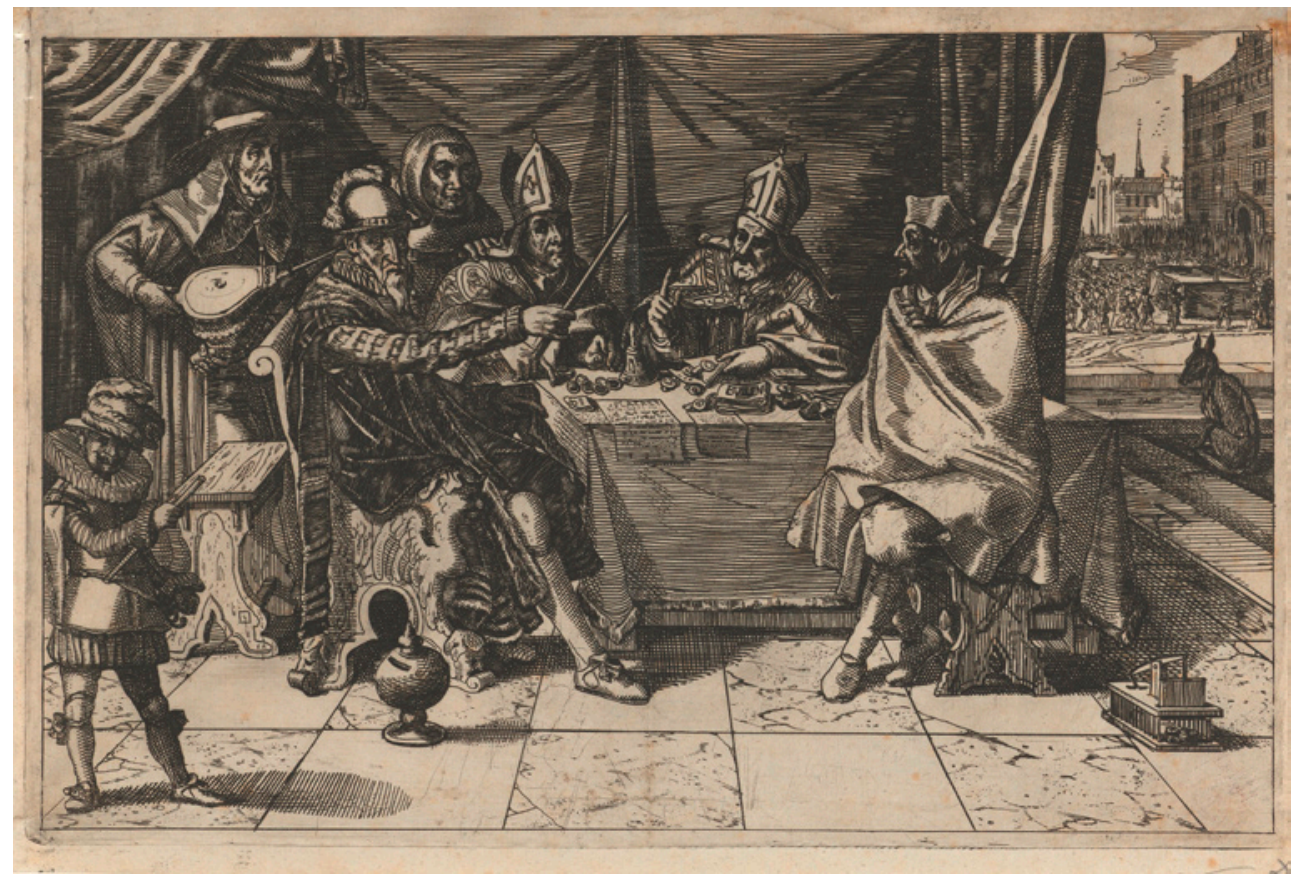

Fig. 1a. Image of the Old and New Time, Rijksmuseum Amsterdam.

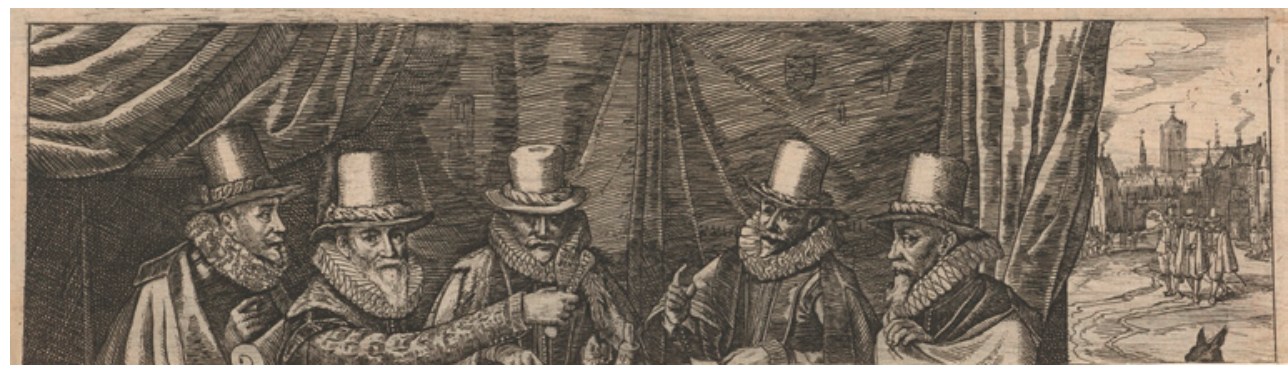

Fig. 1b. Detail of fig. 1a. By flipping over the top half the duke of Alba appears in conference with his Council of Troubles. 
Advocate Jacob van den Eynde. ${ }^{59}$ The duke, whose cruel image had been used to convince Netherlanders to keep on fighting Spain, was now deployed by Remonstrants for a new purpose: to show that the liberty of conscience was being squandered.

This argument can be illustrated by an account of a Counter-Remonstrant disruption of an Arminian service. An anonymous author in 1619 criticised Counter-Remonstrant measures against clandestine Remonstrant preaching just outside Rotterdam, where Arminianism had also been banned. In his text, he denounces the hypocrisy of the CounterRemonstrants: 'how often they generally shouted against the procedures against them by the duke of Alba [...] is still fresh in the memory'. But since the 'bloodthirsty Calvinists or Gomarists [...] by force of arms, have gained the upper hand' not much was left of these hard-won liberties. ${ }^{60}$ In a handwritten propagandistic poem circulating in The Hague, the juxtaposition between past and present is made even stronger. 'The duke of Alba has exercised tyranny in Holland / On equal terms the Prince [Maurice] establishes dominion / You ask why it happens? / I say, that in the prince of Orange / the duke of Alba's soul has come from Spain'.61

\section{Conclusion}

During the Twelve Years Truce, Remonstrants and Counter-Remonstrants contested the moral ownership of the communal past. They both drew from the inclusive canonical narratives about the Revolt to bolster their arguments and thereby turned the past into a rhetorical battleground. This article has shown how a canonical narrative that was aimed at blackening the foreign enemy could become the stake of disagreements in domestic politics.

There are several reasons why public memories of the Revolt were used. In the first place, an important condition for using episodes of the Revolt successfully as a political weapon was that they were widely known and recognised as important. Since the episodes had already reached canonical status in the discussions about war and peace, people could easily understand or at least identify with the historical references, which

59 Den Tex, Oldenbarnevelt, vol. 3, 626.

60 Anonymous, Sommier verhael van de wreede handelinghe der bloet-dorstighe Calvinisten, ghepleeght teghen de Remonstranten buyten Rotterdam (s.l., 1619), 3-4.

61 Cited from Van Deursen, Bavianen en slijkgeuzen, 360. 
accordingly carried rhetorical value. Secondly, the secular history of the Revolt was just another way of appealing to a more general audience. At the beginning of the religious troubles, academic discussions about doctrine prevailed. But as religion and politics became even more entangled than usual, both factions needed to address a more general audience that was not necessarily trained in theology. The widely known history of the Revolt was something many people could associate with, and it could therefore serve as an effective frame of reference. Thirdly, I found that the appropriation of memories of the past by one party forced the other party to do the same, however reluctantly. This resulted in two alternative interpretations of history and a memory war. Ultimately the 'winner' of this memory war was decided not by rhetoric but by 'real' actions. Due to the ultimate victory of the Counter-Remonstrants, the canonical narratives about the Revolt became associated not only with anti-Hispanism but also with Calvinist orthodoxy and the prince of Orange, giving the canon an internal religious and political flavour which, as an inclusive anti-peace narrative, it had previously lacked. 